\title{
Experience in the Surgical Management of Two Cases with Acromegaly
}

\author{
Eka J. Wahjoepramono
}

\begin{abstract}
Acromegaly is a chronic disorder that usually develops over many years due to long term exposure to elevated levels of growth hormone (GH) most typically caused by a somatotrophic cell pituitary adenoma. It has an annual incidence of approximately 3-4 cases / million. A diagnosis of acromegaly is made based on the clinical presentation, biochemical and radiologic finding. The classical feature is the change in appearance and acral enlargement. No single therapy is comprehensively successful in controlling the disease. Surgical, medical and radiation treatments are available for lowering GH and insulin-like growth factor I (IGF-I) hypersecretion, controlling pituitary tumor mass effects, and lowering morbidity.
\end{abstract}

Keywords : acromegaly, growth hormone, surgical therapy. (J I Bedah Indones. 2007; 35(2): 65-7)

\section{Pengalaman Penatalaksanaan Operatif pada Dua Kasus Akromegali}

\begin{abstract}
Abstrak
Akromegali adalah suatu penyakit kronis yang umumnya berkembang dalam beberapa tahun, akibat paparan growth hormone yang berlebih dalam jangka waktu yang lama yang disebabkan oleh somatotrophic cell pituitary adenoma. Insiden terjadinya akromegali adalah sebanyak 3 - 4 kasus per satu juta penduduk. Diagnosis akromegali dibuat berdasarkan gambaran klinis, pemeriksaan biokimiawi dan gambaran radiologi. Gambaran klasik akromegali adalah perubahan wajah dan pembesaran akral. Penatalaksanaan akromegali yang maksimal dilakukan dengan cara terapi kombinasi, yaitu pembedahan, medikamentosa dan terapi radiasi yang efektif untuk menurunkan kadar growth hormone dan IGF-I, mengontrol efek massa, serta menurunkan morbiditas.
\end{abstract}

Kata kunci : akromegali, growth hormone, terapi operasi. (J I Bedah Indones. 2007; 35(2): 65-7)

\section{INTRODUCTION}

Acromegaly is chronic endocrine disease that results when the pituitary gland produces excess $\mathrm{GH}$ after epiphyseal plate closure, which is characterized by enlargement of the extremities. The most common cause of increased $\mathrm{GH}$ production in acromegaly is a $\mathrm{GH}$-secreting pituitary tumor, a benign tumor called an adenoma. ${ }^{1-5}$

Acromegaly is uncommon, with an incidence of approximately 3-4 cases/million persons/year, the prevalence is about 60/million, and the mean age at diagnosis is 40-45 years. No clear relationship exists between incidence and race. Acromegaly occurs with equal frequency in males and females. ${ }^{3,4,6,7}$

The pituitary produces several important hormones that control body functions. They usually cascade in a series. This cascade begins in hypothalamus, which makes growth hormone-releasing hormone $(\mathrm{GHRH})$ that stimulate the pituitary gland to produce GH. Secretion of GH stimulates the liver to produce another hormone called IGF-I and is the primary mediator of growth promotion, leading to proliferation of bone, cartilage, soft tissues and increase in size of other organs. In pituitary adenoma, tumors have a mutation in the alpha subunit that stimulate GHRH receptor activation, resulting in autonomous $\mathrm{GH}$ secretion. If the pituitary continues to make $\mathrm{GH}$ independent of the normal regulatory mechanisms, the level of IGF-I continues to rise, leading to bone overgrowth and organ enlargement. ${ }^{3,4,8}$

\section{CASE SERIES}

Case 1

Mr. B, 34 years old came to neurosurgery clinic Siloam Hospitals with chief complain of changes the sized of his hands and foot. Physical examination found acromegaly (Figure 1). His laboratory examination showed increased GH $109 \mathrm{ng} / \mathrm{mL}$. MRI showed expansion and a lobulated mass of the sella turcica appropriate with macroadenoma hypophyse,
Faculty of Medicine - Pelita Harapan University/

Neurosurgery Departement Siloam Hospital Lippo Karawaci, Banten 
the size was $36.9 \times 26.2 \times 36.1 \mathrm{~mm}$. There were extension to the suprasellar region with stretched chiasma opticum, and infiltration of the cavernous sinus with encasement of the carotid siphon especially on the right side (Figure 2).

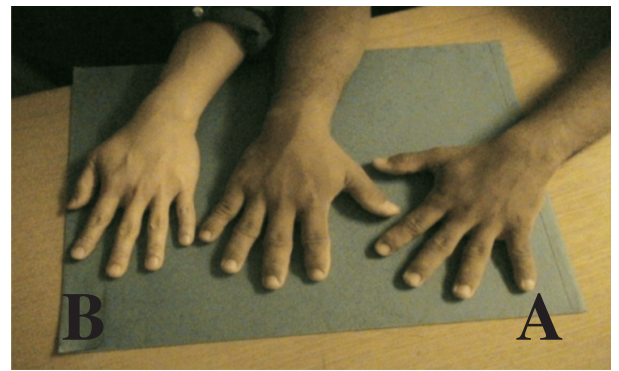

Figure 1 . The right side is acromegaly hands $(\mathrm{A})$ as it is compared to the normal hand on the left side (B)

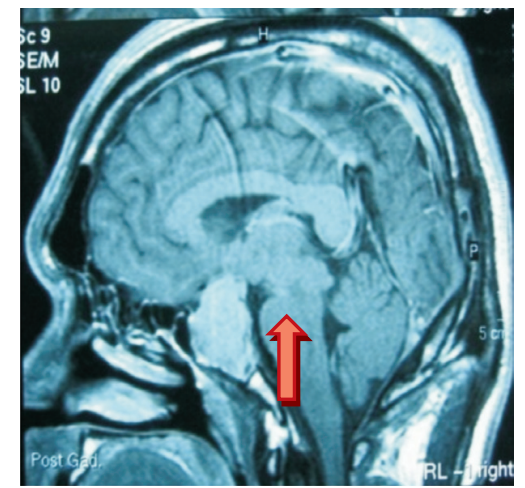

Figure 2. Preoperative MRI showed macroadenoma hypophyse

Our diagnosis was acromegaly due to pituitary adenoma and we suggested surgical treatment. Two weeks later, he came with complain of decreased visual acuity and field. Ophthalmological examination showed decreased light sensitivity of the left eye. Three weeks after the second visit, he complained of paresthesiae in both hands. EMG examination showed decreased velocity in N.medianus and N.ulnaris in both hands. The right hand being worse than the left. This result appropriate to carpal tunnel syndrome (CTS).

One month later, he decided to undergo the surgical treatment. A transphenoidal procedure was done to remove the pituitary adenoma, and also release of the CTS. Histological examination showed a cellular tumor consisting of small uniform cells with round nuclei and small nucleouli. The cytoplasm was granular and eosinophilic with vacuoles, findings appropriate for eosinophilic adenoma. His condition improved following surgery. One week later, the laboratory examination showed decrease of GH $25 \mathrm{ng} / \mathrm{mL}$. CT scan showed residual intrasellar mass with fat tissue extending to the right parasellar area and right carotid siphon artery. There was no longer a suprasellar expansion (Figure 3).

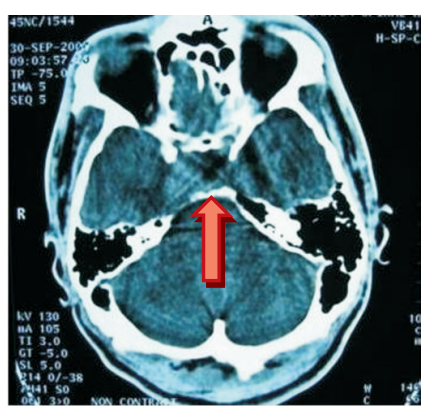

Figure 3. Postoperative CT Scan. Total removal of pituitary tumor

He was routinely followed up, and serial $\mathrm{GH}$ results were $29.2 \mathrm{ng} / \mathrm{mL}, 52 \mathrm{ng} / \mathrm{mL}, 36 \mathrm{ng} / \mathrm{mL}, 89.2 \mathrm{ng} / \mathrm{mL}, 6 \mathrm{ng} / \mathrm{mL}$. On December 29,2007, GH was $30 \mathrm{ng} / \mathrm{mL}$ and the CT scan showed a wide sella with residual mass coverring the internal wall of the sella $0.8 \mathrm{~mm}$, a cystic defect in the center of the sella, and fat tissue in the sellar floor and sphenoid sinus.

\section{Case 2}

Mrs. S, 47 years old came to the neurosurgery clinic at Siloam Hospital with a chief complain of changes in appearance, including thickening of the lips and increasing sizes of her hands (Figure 4). She also felt paresthesiae in the left hand. Physical examination showed the appearance of acromegaly. Laboratory examination showed only slightly increased $\mathrm{GH}$ at $7.2 \mathrm{ng} / \mathrm{mL}$. The MRI showed a small nodule $(0.72 \mathrm{~cm}$ in diameter $)$ in the right inferior aspect of the hipophyse which did not enhanced with contrast, considered appropriate for pituitary adenoma (macroadenoma). The diagnosis was acromegaly due to pituitary adenoma.

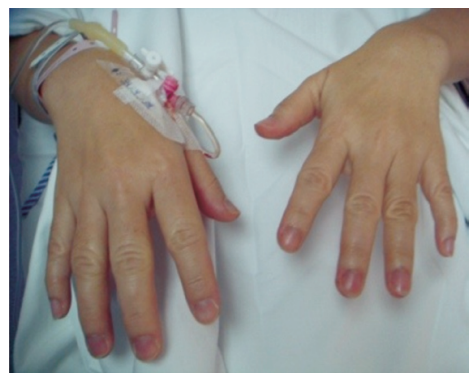

Figure 4. Increased size of the hands

One week later we did the surgery using a transphenoidal procedure. After surgery, the laboratory examination showed GH $6.5 \mathrm{ng} / \mathrm{mL}$. The CT scan result showed minimal bleeding in the sphenoid sinus. Histological examination showed cellular tumor consisting of small cells with uniform nuclei, and granular acidophilic cytoplasm, consistent with adenoma hyphophyse. Her condition improved following surgery, and has continued to improve after discharge. One month later the laboratory examination showed GH level $4.5 \mathrm{ng} / \mathrm{mL}$. 


\section{DISCUSSION}

The diagnosis of acromegaly is based on clinical, biochemical and radiologic finding. Initially the symptoms may be caused by the mass effect of the tumor such as headache, visual field defects or other cranial nerve palsies, as seen in case 1 . The most characteristic feature is a change in appearance such as comprising coarsening of the facial features, fleshy enlargement of the nose, thickening of the lips as seen in case 2 which occur simultaneously. Acral enlargement (increase in soft tissues) results in the other classical clinical manifestations as it could be seen in these two cases. Musculoskeletal abnormalities are the more disabling component in acromegalic patients which may include carpal tunnel syndrome, peripheral neuropathy, paresthesias, and spinal cord or nerve root compression from bony overgrowth as they could be seen in case 1 and case 2.,7-10

Biochemical diagnosis is made by assessing autonomous secretion of GH during an OGTT. Clearly elevated GH levels (>10 ng/mL) after oral glucose, combined with the clinical picture, or if the $\mathrm{GH}$ level does not decline to below $1 \mathrm{ng} / \mathrm{mL}$ during the test, secure the diagnosis of acromegaly, while a normal $\mathrm{GH}$ level $(<5 \mathrm{ng} / \mathrm{mL})$. In these two cases the $\mathrm{GH}$ level are high; case 1 showed GH level $109 \mathrm{ng} / \mathrm{mL}$ and case 2 showed GH level 7,2 ng/mL. In addition, measurement of IGF-I is useful to gauge integrated GH secretion. IGF-binding protein-3 (IGFBP-3), GHRH concentration and prolactin can be measured also. ${ }^{7,8,11-13}$

Pituitary MRI with the administration of contrast is the most sensitive imaging study for determining the source of excess growth hormone. Adenomas more than $2 \mathrm{~mm}$ in diameter can be visualized. ${ }^{4,6,7}$

The goals of treatment are to reduce $\mathrm{GH}$ production to normal levels, to relieve the pressure that the growing pituitary tumor exerts on the surrounding brain areas, to preserve normal pituitary function, and to reverse the symptoms of acromegaly. A multimodality approach usually requires surgery as the first line of treatment, followed by medical therapy and radiation therapy. Candidates for urgent surgical treatment are those who present with severe mass effect. The standard procedures for pituitary adenoma is transsphenoidal surgery. Three different types of medical therapy are currently used; somatostatin analogues, dopamine agonists, GH receptor antagonists. Pituitary irradiation is usually used as an adjunct to pituitary surgery when GH levels remain elevated, or for tumors that have recurred or persisted after surgery in patients with resistance to or intolerance of medical treatment. The two types of radiation are conventional and stereotactic. Gamma knife is one of stereotactic radiosurgery, which delivers a single radiation fraction to a small tumor target. Gamma Knife represents a safe, efficacious treatment and less common complications. Neuropathological examination (immunohistochemistry) of the tumor documented pituitary adenomas and confirmed GH expression. ${ }^{3,4,6,8,14-17}$
In these two cases, because of the mass effect and the level of GH caused symptoms, we decided to do surgical treatment (transsphenoidal surgery) for the first line treatment. The surgical result was good. The patient condition improved following surgery and GH level was decreased.

\section{REFERENCES}

1. Wikimedia Foundation Inc. Acromegaly. [http://en.wikipedia. org/wiki/Acromegaly]. 2008. [updated 2008 April 22; cited 2008 May 03]

2. Ayuk J, Sheppard MC. Growth hormone and its disorders. Postgrad Med J. 2006; 82:24-30.

3. Carroll PV, Jenkins PJ. Acromegaly. [http://www.endotext. $\mathrm{org} /$ neuroendo/neuroendo5e/neuroendoframe5e.htm]. 2007. [updated 2007 March 29; cited 2008 May 03].

4. Schwartz RA. Acromegaly. [http://www.emedicine.com/med/ topic593.htm]. 2008. [updated 2008 March 18; cited 2008 May 05].

5. Melmed S, Casanueva FF, Cavagnini F, Chanson P, Frohman L, Grossman A, et al. Guidelines for acromegaly management. J Clin Endocrinol Metab. 2002; 87(9) : 4054-58.

6. American Association of Clinical Endocrinologists. [http://www. aace.com/pub/pdf/guidelines/AcromegalyGuidelines2004.pdf]. Medical guidelines for clinical practice for the diagnosis and treatment of acromegaly. [cited 2008 May 05]. Endocr Pract. 2004; 10(3): 213-25.

7. Thapar K, Laws E R. Pituitary tumor : functioning and non functioning. In : Winn H R. Dacey R G, et al. Youmans Neurological Surgery. 5th ed. USA: Saunders, Elsevier Inc; 2004. p. 1189-94.

8. Melmed S. Acromegaly. N Engl J Med. 2006; 355: 2558 - 73.

9. Molitch ME. Clinical manifestations of acromegaly. Endocrinol Metab Clin North Am. 1992; 21(3): 597-614.

10. Melmed S, Jackson I, Kleinberg D, Klibanski A. Current treatment guidelines for acromegaly. J Clin Endocrinol Metab. 1998; 83(8): 2646-52.

11. Colao A, Ferone D, Marzullo P, Lombard G. Systemic complications of acromegaly: epidemiology, pathogenesis, and management. Endocr Rev. 2004; 25(1): 102-52.

12. Khandwala HM. Acromegaly. [http://www.emedicine.com/ MED/topic27.htm]. 2007. [updated 2007 Sep 18; cited 2008 May 06].

13. Freda PU. Current concepts in the biochemical assessment of the patient with acromegaly. Growth Horm IGF Res. 2003; 13:171-84.

14. Cozzi R, Attanasio R, Lodrini S, Lasio G. Cabergoline addition to depot somatostatin analogues in resistant acromegalic patients: efficacy and lack of predictive value of prolactin status. Clin Endocrinol (Oxf). 2004; 61: 209-15.

15. Jenkins PJ, Bates P, Carson MN, Stewart PM, Wass JA. Conventional pituitary irradiation is effective in lowering serum growth hormone and insulin-like growth factor-I in patients with acromegaly. J Clin Endocrinol Metab. 2006; 91: 1239-45.

16. Castinetti F, Taieb D, Kuhn JM, Chanson P, Tamura M, Jaquet $\mathrm{P}$, et al. Outcome of gamma knife radiosurgery in 82 patients with acromegaly: correlation with initial hypersecretion. J Clin Endocrinol Metab. 2005; 90: 4483-8.

17. Minniti G, Traish D, Ashley S, Gonsalves A, Brada M. Risk of second brain tumor after conservative surgery and radiotherapy for pituitary adenoma: update after an additional 10 years. J Clin Endocrinol Metab. 2005; 90: 800-4. 